\title{
Florencia Garramuño traduz Graciliano Ramos
}

Jorge Wolff

\section{Resumo:}

O texto abaixo apresenta o ensaio de Florencia Garramuño, que introduz sua própria tradução espanhola de Vidas secas, de Graciliano Ramos, lançada em 2001, e procura contextualizá-lo brevemente no âmbito das trocas culturais entre Argentina e Brasil. Após esta apresentação segue a versão brasileira de "El regionalismo equívoco de Vidas secas", em que a autora propõe uma reavaliação das relações entre os conceitos de modernismo, regionalismo e realismo no âmbito da cultura brasileira da primeira metade do século $X X$. Diretora do Programa de Cultura Brasileira da Universidad de San Andrés, em Buenos Aires, e autora de Modernidades primitivas. Tango, samba e nação (Editora da UFMG, 2009) e La experiencia opaca (FCE, 2009), Florencia Garramuño traduziu, entre outros, Grande sertão: veredas de Guimarães Rosa (com Gonzalo Aguilar), Em liberdade de Silviano Santiago, e coordenou a versão espanhola de Os sertões, de Euclides da Cunha para a editora Fondo de Cultura Económica.

Palavras-chave:

Modernismo; regionalismo; realismo; tradução

A tradutora e ensaísta Florencia Garramuño publicou uma nova versão de Vidas secas (1938) em espanhol em 2001 pela editora Corregidor, de Buenos Aires. Nova porque circulou durante décadas uma anterior, feita pelo escritor Bernardo Kordon (1915-2002) e publicada em 1947, portanto menos de dez anos após o surgimento do próprio livro. Além de refazer a versão castelhana, Garramuño inclui o ensaio "O regionalismo equívoco de Graciliano Ramos", que é ao mesmo tempo reflexão e introdução ao universo do escritor e do modernismo brasileiro.

\footnotetext{
${ }^{*}$ Professor de Literatura Brasileira da UFSC.
} 
Espécie de John dos Passos portenho, Bernardo Kordon, que começou a publicar no fim dos anos 30, foi um escritor globe-trotter, um viageiro que mergulhou precocemente na China maoísta, além de ter sido tradutor de autores franceses e brasileiros, como Graciliano Ramos e José Lins do Rego, seus contemporâneos. Teve narrativas transformadas em filmes com o sabor de neorealismo urbano em que se iniciou como escritor.

Cinquenta anos depois de Kordon, Florencia Garramuño propõe uma nova versão do relato famoso em que se destaca o cuidado em relação a expressões locais empregadas pelos sertanejos, que são mantidas tal qual e destacadas com itálico, como é o caso dos vocábulos catinga, catingueira, mandacaru, xique-xique, preá, juazeiro, molungo, sertanejo, aboio, jatobá, macambira, baraúna, quipá, urubu, alastrado e poucas mais, sendo Graciliano Ramos um escritor de vocabulário altamente concentrado. A observação a respeito da decisão de manter os localismos na língua de origem se encontra no próprio ensaio: são termos usados quase exclusivamente pelos habitantes de certa região do nordeste, muitas vezes completamente desconhecidos no resto do país, o que justifica sua permanência. Trata-se de um gesto significativo que aponta a uma postura diferente, uma vez que, seguindo a maneira espanhola, os hispano-americanos sempre traduziram tudo, do título do disco ao primeiro nome do escritor inglês. Como escreve a ensaísta,

A proliferação de nomes de plantas e de animais típicos do nordeste vai criando uma ciência natural que está também em função desse estranho acercamento e distanciamento simultâneo. Os nomes, bastante específicos e não necessariamente conhecidos para um brasileiro de outra região, não encontram neste romance regionalista - como encontram em muitos outros - um vocabulário para sua explicitação: permanecem conforme pronunciados pelos personagens, parte de seu mundo para alguns indecifrável. Funciona dessa mesma maneira a gramática de Graciliano, uma gramática precisa, artificial e portuguesa demais num momento em que, desde o Modernismo, se propunha escrever como falamos. Graciliano explica: os sertanejos falam assim.

Esta entronização da língua brasileira pela via argentina é parte da reconfiguração das relações entre o âmbito brasileiro e o hispano-americano a partir do final do século XX, passando pelos campos econômico, político e cultural, de que a coleção Vereda Brasil, da editora Corregidor (dirigida por Maria Antonieta Pereira, Gonzalo Aguilar e a própria Florencia Garramuño), é um posto avançado, tendo publicado antes de Vidas secas, uma seleção de 
Escritos antropófagos de Oswald de Andrade e outra de Sátiras y maledicencias de Gregório de Matos; nesta última, para dar uma mostra da ativação do debate proposta pelo selo, encontram-se perfilados ensaios de Haroldo de Campos e João Adolfo Hansen, que, como se sabe, mantêm posições distintas em relação à "musa praguejadora" da Bahia e ao barroco no Brasil. Depois, seguiriam publicando novas traduções comentadas, entre ensaio, poesia, conto e romance, de Machado de Assis, Clarice Lispector, Flora Süssekind, Silviano Santiago, José Guilherme Merquior, Bernardo Carvalho, Ana Cristina César, Paulo Leminski, João Almino, Ferreira Gullar, José de Alencar, e uma antologia de contos, Vereda tropical.

No ensaio introdutório a Vidas secas, a ensaísta começa fornecendo uma "latino-americanização" do debate sobre o impacto modernizador da década de 1920 no Brasil, tomando o quarto e mais famoso relato de Graciliano Ramos como "texto-espelho": Ángel Rama e Emir Rodríguez Monegal insistem em separar regionalismo e modernismo, ao contrário de boa parte da crítica brasileira, a exemplo de Antonio Candido, para quem o regionalismo supõe o modernismo e em certo sentido o continua, conforme lembra Garramuño. "Sua prosa seca e despojada só pode ocorrer uma vez que Oswald e os paulistas tivessem limpado a prosa brasileira 'do mal da eloqüência oca' (Paulo Prado)". Coloca, assim, o chamado regionalismo nordestino "dentro da esteira do modernismo paulista", com o que problematiza - com cautela mas sem receio de enfrentar questões polêmicas - as relações entre ambos, a fim de discutir se o de Graciliano Ramos não seria antes uma espécie de "novo regionalismo", mais ligado a Oswald e Mário de Andrade, enquanto certos romances regionalistas de Jorge Amado estariam mais próximos de um Plínio Salgado.

Para desdobrar a proposição, o ensaio sugere que o escritor alagoano trabalha sobre os "limites do realismo anterior", relacionando-o a Gustave Flaubert no que concerne ao extremo cuidado com a linguagem. Trata-se, segundo Garramuño, do início do cancelamento do modernismo brasileiro, assim como Flaubert fez explodir o modernismo europeu. Entre o regionalismo, o modernismo e o realismo, Graciliano Ramos escreve sem explicar nem pontificar: "um mandacaru escrevendo", como diria Oswald de Andrade, mandacaru cuja linguagem tampouco documenta ou representa alguma coisa, sendo essa própria seiva ou coisa. "Não haveria ali", escreve, "uma preocupação realista [...] mas um deslocamento da política para outro espaço" - espaço cuja concepção de linguagem implica construir a realidade com um sentido permanentemente "inacabado e incompleto". Em síntese, o "texto pobre" contra 
a "retórica da falação", como nos lembra, invocando aqui Haroldo de Campos. Mas deixemos a ensaísta falar, agora em versão brasileira.

\title{
Title:
}

Florencia Garramuño translates Graciliano Ramos

\begin{abstract}
:
The text bellow presents an essay by Florencia Garramuño, which introduces her own translation of Spanish of the novel Vidas secas, by Graciliano Ramos, published in 2001, and seeks to contextualize briefly the essay within the cultural exchanges between Brazil and Argentina. After the presentation follows the Brazilian version of "El regionalismo equívoco de Vidas secas" in which the author proposes a reassessment of the relations between the concepts of modernism, regionalism and realism within the context of Brazilian culture during the first half of the twentieth century. Director of the Brazilian culture program at San Andrés University in Buenos Aires, Florencia Garramuño is the author of Modernidades primitivas: Tango, samba e nação (Editora UFMG, 2009) and La experiencia opaca. Literatura y desencanto (FCE, 2009). Translated Gran sertón: veredas by Guimarães Rosa (with Gonzalo Aguilar), En libertad by Silviano Santiago, among others, and organized the Spanish version of LoS sertones by Euclides da Cunha for Fondo de Cultura Económica.
\end{abstract}

\section{Keywords:}

Modernism; regionalism; realism; translation 


\section{0 regionalismo equívoco de Vidas secas Florencia Garramuño*}

\section{Modernidade e regionalismo}

O impacto modernizador da segunda década do século XX irrompe na América Latina inaugurando um conflito que preocupará a crítica latino-americana por vários anos, que foi denominado por Ángel Rama como o conflito entre vanguardismo e regionalismo (RAMA, 1985). Graciliano Ramos e, especialmente, seu Vidas secas, publicado em 1938, aparece como uma espécie de texto-espelho cuja superfície revela claramente os diferentes matizes que este conflito adquiriria no Brasil.

Regionalismo e modernismo (a vanguarda brasileira dos anos 20) não foram no Brasil termos antagônicos (como não o foram também às vezes, mas talvez de uma maneira muito mais difícil de perceber, em outras zonas da América Latina) e sim variações de um processo de modernização que adquiriu, na imensidão do Brasil, cristalizações diversas. ${ }^{1}$ Quando Oswald de Andrade e Mário de Andrade em São Paulo agitavam as águas estanques do pré-modernismo, ${ }^{2}$ Gilberto Freyre inaugurava em Recife um congresso regionalista que, ao longo dos anos

\footnotetext{
* Professora da Universidad de San Andrés (Buenos Aires, Argentina), onde dirige o Programa de Cultura Brasileira.

1 Tanto Ángel Rama (1985) quanto Emir Rodríguez Monegal (1963) insistem em ver regionalismo e modernismo brasileiros como termos antagônicos (Rodríguez Monegal fala do regionalismo nordestino como contramovimento do modernismo), atitude que se encontra ausente na maior parte da crítica brasileira que reconhece, apesar das inimizades pessoais a relação do vanguardismo com o regionalismo. Assim, para Candido (1989, p. 181-198) o regionalismo supõe o modernismo e em certo sentido o continua. Para além das leituras críticas, também os documentos dos atores do debate parecem lançar uma luz ambígua sobre o problema, já que enquanto, por exemplo, Gilberto Freyre fará gestos de aproximação com Oswald e este em direção a quem chamou de "o herói de Apipucos", outras relações entre regionalistas e modernistas não foram tão amistosas. No entanto, o central talvez não passe por aí mas pelos próprios textos produzidos dentro destes dois movimentos e as funções e intenções que neles foram postuladas. Para a aproximação de Freyre com Oswald e o modernismo de 22, cf. FREYRE, 1967; para os de Oswald com Freyre, cf. ANDRADE, 1991, p. 97103.

${ }^{2}$ A percepção do período da literatura brasileira que vai aproximadamente de 1890 à irrupção da vanguarda como momento de repetição e tédio é o gesto divisor do campo intelectual sobre o qual se institui a vanguarda modernista. Esse período continuou sendo percebido desta maneira na tradição crítica brasileira até uma série de reavaliações produzidas a partir de 1980 que vão pressupor, além disso, uma leitura renovada do próprio modernismo: já em 1945 Oswald via em um dos antagonistas mais fervorosos do modernismo, João do Rio, insinuações do que viria a ser o modernismo. Para a reavaliação do pré-modernismo, cf. SÜSSEKIND, Flora (1987), PAES, José Paulo (1985), HARDMAN, Francisco Foot (1983), RESENDE, Beatriz (1993) e o volume que compila uma série de comunicações organizadas com este motivo pela Casa de Rui Barbosa, Sobre o Prémodernismo (1988).
} 
e através de uma série de manobras destinadas a tal efeito, construiria a idéia da simultaneidade da reforma e da mudança em ambos espaços. ${ }^{3}$

Mas regionalismo de 30 e modernismo brasileiro não são apenas dois momentos de modernização da cultura brasileira: compartilham, além dessa ânsia modernizadora, uma mesma preocupação pela nacionalização da cultura. É que para o Brasil, como para muitos dos países latino-americanos, as décadas de 20 e 30 descobrem no mandato da modernização uma preocupação que coincide com a necessidade de nacionalizar a cultura. Ser moderno será, então, ser nacional, como assinala Tarsila do Amaral - a inevitável iconógrafa do modernismo brasileiro - numa carta escrita em Paris e dirigida a sua família em 1923:

Sinto-me cada vez mais brasileira: quero ser a pintora da minha terra. Como agradeço por ter passado na fazenda a minha infância toda. As reminiscências desse tempo vão se tornando preciosas para mim. Quero, na arte, ser a caipirinha de São Bernardo, brincando com bonecas de mato, como no último quadro que estou pintando. (...) Não pensem que esta tendência brasileira na arte é malvista aqui. Pelo contrário, o que se quer aqui é que cada um traga contribuição de seu próprio país. Assim se explicam o sucesso dos bailarinos russos, das gravuras japonesas e da música negra. Paris está farta de arte parisiense. ${ }^{4}$

A narrativa de Graciliano Ramos supõe, como disse Antonio Candido, o impacto revolucionário do modernismo: sua prosa seca e despojada só pode ocorrer uma vez que Oswald e os paulistas tivessem limpado a prosa brasileira "do mal da eloqüência oca" (PRADO, 1974) que imperava no Brasil e da qual Mário de Andrade traça uma genealogia paródica na "Carta pras Icamiabas" incluída em seu Macunaíma. Mas a narrativa de Graciliano Ramos não somente supõe essa revolução prévia, não somente se constrói sobre essa primeira operação de despojamento da escrita possibilitada pelo Modernismo, como também introduz, enquanto corte crítico radical, um impacto de iguais ou maiores conseqüências dramáticas, onde a suposta representação de uma realidade regional

\footnotetext{
${ }^{3}$ O Congresso de escritores regionalistas foi realizado em Recife em 1925 e deu origem ao Manifesto de Recife com apenas alguns parágrafos. Gilberto Freyre publica no entanto outra versão muito mais volumosa do manifesto em 1952, numa edição do Ministério da Educação, com o título de Manifesto Regionalista que foi vista como uma manobra de Freyre para magnificar sua participação no que ele denominou "movimento regionalista, tradicionalista e, a seu modo, modernista de Recife". Além das manobras de Freyre, Oswald de Andrade recupera posteriormente para a Semana de 22 a participação do regionalismo na modernização cultural do Brasil. Diz Oswald em "Informe sobre o Modernismo": "Em São Paulo, depois da ação do comando, que é a Paulicéia Desvairada de Mário de Andrade, o movimento 'Pau-Brasil' anuncia o slogan 'Poesia de exportação contra poesia de importação'. E Gilberto Freyre abre o seu apostolado nacional em Recife, criando para o Brasil uma sociologia efetiva e totêmica" (ANDRADE, 1991).

${ }^{4}$ Tarsila do Amaral, em carta de 19 de abril de 1923, citada por Zílio, Carlos (1997, p. 48).
} 
acompanha uma tensão modernizadora às vezes tão violenta quanto a que os modernistas paulistas imprimiram à tradição brasileira.

Colocar o regionalismo nordestino dentro da trilha do modernismo paulista não significa, no entanto, homogeneizar dois tipos de respostas diferentes diante de um mesmo momento histórico e impulso simultaneamente modernizador e nacionalizador. Implica sim perguntar se a coincidência nessa mesma preocupação não distribui de outra maneira as linhas da vanguarda e do regionalismo, distribuindo sobre essas etiquetas um desenho diferente em que certos escritores regionalistas como Graciliano Ramos não ficariam, apesar de sua própria percepção do campo intelectual da época, ${ }^{5}$ mais próximos de um Oswald ou de um Mário, enquanto outros modernistas como Plínio Salgado que mais tarde se separaria da vanguarda antropófaga - poderiam ver-se, ao contrário, mais próximos de outros regionalistas, ou pelo menos de alguns dos romances regionalistas de Jorge Amado.

Não se trata, em todo caso, de aproximar o Graciliano tímido e áspero ao claramente alvoroçado Oswald, mas sim de marcar que, enquanto alguns regionalistas de 30 pensaram na língua como instrumento transparente para a representação de uma realidade, o uso que Graciliano Ramos vai fazer desse instrumento é uma forma, talvez mais pausada, quiçá mais lânguida, de pôr em questão a relação entre literatura e representação. Enquanto Jorge Amado, na nota preliminar a Cacau (1933), declara: "Tentei contar neste livro, com um mínimo de literatura para um máximo de honestidade, a vida dos trabalhadores das fazendas de cacau no Sul da Bahia", a escrita de Graciliano Ramos, em graus variados de intensidade de livro a livro, inicia já com seu primeiro romance um processo de distanciamento e de desconfiança diante da capacidade do discurso de representar e, mais tarde, de mudar o mundo, que levará até o extremo de duvidar de sua própria escrita autobiográfica. Memórias do cárcere (1953), livro póstumo que relata sua própria experiência como preso político do regime de Getúlio Vargas, começa com uma advertência que desenha o avesso daquela frase de seu amigo Jorge Amado:

Não resguardei os apontamentos obtidos em largos dias e meses de observação: num momento de aperto fui obrigado a atirá-los na água. Certamente me irão fazer falta, mas terá sido uma perda irreparável? Quase me inclino a supor que foi bom privar-me desse material. Se ele existisse, ver-me-ia propenso a consultá-lo a cada instante, mortificar-

\footnotetext{
${ }^{5}$ Cf. MIRANDA, Wander Melo, no artigo incluído neste volume [referência a "Sin patria", panorama de vida e obra do autor incluído após a tradução de Vidas secas], e MONEGAL, Emir Rodríguez, op. cit.
} 
me-ia por dizer com rigor a hora exata de uma partida, quantas demoradas tristezas se aqueciam ao sol pálido, em manhã de bruma, a cor das folhas que tombavam das árvores, um pátio branco, a forma dos montes verdes, tintos de luz, frases autênticas, gestos, gritos, gemidos. Mas que significa isso? Essas coisas verdadeiras podem não ser verossímeis. E se esmoreceram, deixá-las no esquecimento: valiam pouco, pelo menos imagino que valiam pouco. ${ }^{6}$

Se toda cultura nacional não é mais do que um espaço unido pelo conflito constante, a década de 30 será no Brasil uma década cheia de revoluções na ordem política e tensões sociais que parece aprofundar o que João Luis Lafetá (2000) denominou como a passagem de um projeto estético a um projeto ideológico, marcado pela exasperação dos debates e disputas. Qualquer das posições que se tome a respeito não poderá deixar de notar que, apesar de certa tendência a explicar movimentos e situações através da referência ao que acontecia na Europa, as décadas de 20 e 30 e as transformações que ocorrem no campo da cultura durante este período respondem, mais que à influência externa, ao clima de tensões sociais que se vive na década de 30 no Brasil, cheia não somente de revoluções (HARDMAN, 1983), mas também de mudanças abruptas e de uma crescente heterogeneidade social.

Se o olhar se concentra na década de 30, essas tensões parecem então encontrar uma solução provisória que se revelaria justamente propícia para o surgimento e entusiasmo do regionalismo entendido como forma de modernizar a cultura. Trata-se do fim da oligarquia cafeeira, hegemônica até a crise de 30, momento em que uma abrupta queda do preço do café torna impossível continuar subvencionando sua produção, acentuando-se assim os antagonismos de classe e de região. A revolução liderada por Getúlio Vargas, finalmente nomeado presidente, é considerado o momento do fim da República Velha, dominada pela oligarquia do café. A revolução representa a vitória para os grupos burgueses urbanos e industrializados, mas a coalizão que Getúlio liderou era bastante heterogênea e incluía também a participação de algumas oligarquias regionais.

\section{Graciliano Ramos e o regionalismo de $\mathbf{3 0}$}

Maceió (cidade do nordeste brasileiro), um grupo de escritores - Rachel de Queiroz, José Lins do Rego, Jorge Amado e Graciliano Ramos, entre outros que se reúnem em torno de uma mesa para discutir quesões estéticas e

\footnotetext{
${ }^{6}$ RAMOS, Graciliano, Memórias do cárcere, p. 36.
} 
políticas - muitos deles coincidiram num momento ou noutro ao se filiarem ao Partido Comunista - e a circunstância de que a grande maioria deles sejam romancistas e publiquem num curto lapso de tempo romances como $O$ quinze (1930) e João Miguel (1932) de Rachel de Queiroz, Menino de engenho (1932) e Doidinho (1933) de José Lins do Rego, Cacau (1933) e Jubiabá (1935), de Jorge Amado, ou Caetés (1933) e São Bernardo (1934), de Graciliano Ramos, são dados que, agrupados, levam à construção de um fenômeno novo na literatura brasileira de 30 que ganhou nomes como "romance de 30" ou "romance regionalista de $30 "$.

Se por um lado esse renovado interesse pelo romance vinha a substituir uma década marcada pela intensíssima produção poética e certo descuido com a narrativa, por outro implicava também outro tipo de reposição: era, a princípio, diante da narrativa urbana que se publicava mais esporadicamente na época, um tipo de narrativa que se deslocava dos centros até então hegemônicos que tinham sido o Rio e São Paulo mas que não renunciava, no entanto, a um desejo modernizador. A tradição em que se inscrevia e que esse novo romance vinha a questionar era o regionalismo que, desde o século XIX, havia construído no Brasil uma tradição marcada pelo exotismo, o predomínio da busca de uma identidade nacional e os paradigmas positivistas da época. ${ }^{7}$ O romance de $30 \mathrm{e}$ o do nordeste especialmente vêm instaurar nesse campo um corte que significa um tratamento mais coerente da linguagem coloquial, traços impressionistas na técnica da descrição e uma clara atitude reivindicatória (BOSI, 1972).

Numa crônica compilada em Linhas tortas e incluída neste volume por sua estreita relação com a escrita de Vidas secas, Graciliano Ramos estabelece claramente suas diferenças em relação a essa tradição. "A propósito da seca" institui duas linhas de diferenciação diante do romance da seca que encontrarão em Vidas secas sua manifestação ficcional. Ambas linhas constituem os dois centros sobre os quais foi construído o romance da seca: a figura do retirante e a representação do ambiente. Ambas serão retomadas por Vidas secas de modo revolucionário, trabalhando sobre os limites desse realismo anterior.

Vejamos a primeira. Diz Graciliano: "A figura do retirante, celebrado em prosa e verso, inspirou compaixão e certo desprezo, compaixão porque era evidentemente infeliz, desprezo por ser um indivíduo inferior, vagabundo e meio selvagem ou bárbaro". Diante dessa figura sentimental e romântica, Graciliano

\footnotetext{
${ }^{7} \mathrm{O}$ melhor estudo sobre as transformações dessa estética, desde o séc. XIX até a década de 70, é o livro de Flora Süssekind, Tal Brasil, qual romance? Uma ideologia estética e sua história: o naturalismo. Ligia Chiappini Moraes Leite em "Velha praga? Regionalismo literário brasileiro" também estuda os diferentes momentos do regionalismo.
} 
constrói retirantes a partir de estratégias simultâneas de distanciamento e de negação do desprezo.

Junto a esse distanciamento do personagem, a outra linha de diferenciação implica um afastamento da seca como causa da pobreza e miséria do habitante do sertão. Não é indispensável, propõe Graciliano, que a chuva falte para que o camponês pobre se desfaça de seus filhos inúteis:

Essa desorganização talvez não seja efeito somente da seca. Processos rotineiros na agricultura, indústria precária, exploração terrível do trabalhador rural, falta de administração, devem ter contribuído, tanto quanto a seca, ao atraso em que vive a quinta parte da população do Brasil.

Construído sobre estas duas linhas de diferenciação, Vidas secas apresenta uma colocação bastante particular dentro do romance da seca, posto que é um romance onde a seca não está exaustivamente descrita em termos de transformações ambientais e sim a partir da interioridade dos personagens. Ao substituir a explicação da seca pelo paradigma das ciências naturais, como disse Flora Süssekind (1983), pelo paradigma das ciências sociais, Graciliano fixará, com este romance, os limites do realismo.

\section{Um regionalismo sem terra}

"O que sou é uma espécie de Fabiano", diz Graciliano (CANDIDO, 1992, p. 8), evocando talvez conscientemente a famosa frase de Flaubert "Mme. Bovary c'est moi". Flaubert e Graciliano Ramos compartilham não apenas um cuidado extremo com a linguagem, mas também, derivado desta atitude, um decidido trabalho sobre os limites do realismo. Talvez não seja muito arriscado propor que, se Flaubert prepara o assalto do modernismo europeu, Graciliano, do outro lado do arco temporal das vanguardas, inicia o cancelamento do modernismo brasileiro. Porque se o cuidado extremo com a linguagem, com a forma, é visto por alguns teóricos do realismo socialista como contrário à expressão, tanto da realidade quanto do socialismo enquanto ideologia, ${ }^{8}$ por outro lado é evidente que o romance de Graciliano Ramos não abandona de todo o padrão referencial do realismo.

Já no título Vidas secas há uma tensão em direção à abstração e à generalidade que contrasta muito claramente com outras formas de nomear a seca. Pense-se

\footnotetext{
${ }^{8}$ A literatura de Graciliano Ramos foi julgada por um congresso do Partido Comunista Brasileiro como literatura burguesa e decadente justamente por ser considerada uma literatura que se preocupava demais com a forma. Cf. RAMOS, Clara, p. 330.
} 
se não no título do primeiro romance de Rachel de Queiroz, O quinze, também sobre a seca, e que escolhe como título a data de uma das secas mais devastadoras da história do nordeste. Frente a esse alento realista tanto mais forte num título que destaca e assinala uma seca histórica, a generalidade e quase abstração que postula um título como Vidas secas, ${ }^{9}$ quase um oxímoro.

Partindo deste regionalismo que, em vez de regionalizar ou particularizar, desde o título, parece postular justamente o contrário, o romance institui uma série de diferenças e subversões pausadas, cuja soterrada forma de ação consiste em fazer explodir por dentro os pilares desse realismo.

O primeiro: o narrador em terceira pessoa. Esse narrador onisciente, que pode descrever de fora o mundo narrativo sem se ver comprometido com este, ainda que com freqüência identificando-se com seus personagens ou adjudicando-se sobre eles o direito de julgá-los e condená-los moralmente. Ao ser um narrador externo, justamente é o exterior o que tem grande importância. Com freqüência, na ficção regionalista, é esse exterior a matéria do romance, o que levou alguns críticos a denominar este tipo de narrativa de romance da terra. Os personagens estão em função do ambiente, e com freqüência não são senão excrescências do mesmo.

Mas em Graciliano Ramos o narrador em terceira pessoa só serve como apoio ao discurso indireto livre de seus personagens, que desloca a voz autoral até quase fazê-la desaparecer. Nada de moralismos em Graciliano; nada de juízos, de autoridade. As típicas descrições extensas do ambiente são substituídas pela introspecção dos personagens e as percepções que estes têm, sempre carregadas de reflexões, deste espaço exterior. Dos treze capítulos que formam o romance, quase a metade são construídos com o discurso indireto livre de um personagem, de quem além disso ganham o título. Somente uns poucos "Mudança", "Prisão", "Inverno", "Festa", "Fuga" - não têm nome de personagens e poderiam ser concebidos como capítulos que descrevem ambientes e situações costumbristas, mas estas são, também nestes capítulos, vistas desde o interior dos personagens. Se os capítulos com nome de personagem articulam o discurso indireto desse personagem, a diferença em relação aos capítulos "ambientais" está no fato de que a percepção individual é substituída por percepções coletivas que se entretecem em torno dessa situação ou ambiente.

\footnotetext{
9 O quinze instaura também um certo realismo crítico, mas suas operações resultam bastante diferentes daquelas postas em funcionamento por Graciliano Ramos; em certo sentido, até se poderia dizer que são opostas. Rachel de Queiroz em $O$ quinze tende a particularizar, a individualizar de tal maneira o conflito dramático, que este parece perder por vezes todo caráter costumbrista.
} 
O segundo: as descrições de ambientes. A interiorização da perspectiva que funda esse narrador em terceira pessoa que só deixa os personagens falarem impõe também uma interioridade da paisagem. Não é possível esquecer a paisagem do sertão: o manto anil da noite caindo sobre a planície avermelhada, a caatinga rala e ressecada, os urubus sobrevoando seres vivos, prontos para arrancar seus olhos. Mas essas descrições, se é que são tais, vêm indissoluvelmente ligadas aos personagens que as observam, carregadas até tal ponto de reminiscências e insinuações que é difícil saber se vemos a paisagem ou se sentimos como os personagens. O contraste com a versão cinematográfica deste romance - um dos filmes fundacionais de outra vanguarda cinematográfica, o Cinema Novo - revela a radicalidade desse gesto. O filme de Nelson Pereira dos Santos (1963) não pode deixar de incorporar - e não apenas pela especificidade da linguagem cinematográfica - estratégias que foram denominadas de neo-realistas (BURTON, 1991) para relatar o romance. A festa de Natal, por exemplo, é traduzida por uma série de imagens de festas religiosas populares tradicionais que mais parecem versão de um romance de Pérez Galdós que do próprio Vidas secas. Frente a esse costumbrismo, o romance anuncia seu apagamento. Nem santos, nem orações, nem cantos nem pálios; somente as lembranças, as reflexões e as sensações dos personagens que vêm a suplantar o folclorismo da tradicional festa de Natal. Um charuto para Sinhá Vitória, aguardente para Fabiano, latidos de incompreensão para Baleia.

A proliferação de nomes de plantas e de animais típicos do nordeste vai criando uma ciência natural que está também em função desse estranho acercamento e distanciamento simultâneo. Os nomes, bastante específicos e não necessariamente conhecidos para um brasileiro de outra região, não encontram neste romance regionalista - como encontram em muitos outros - um vocabulário para sua explicitação: permanecem conforme pronunciados pelos personagens, parte de seu mundo para alguns indecifrável. Funciona dessa mesma maneira a gramática de Graciliano, uma gramática precisa, artificial e portuguesa demais num momento em que, desde o Modernismo, se propunha escrever como falamos. Graciliano explica: os sertanejos falam assim.

Se a técnica do discurso indireto livre havia sido identificada alguns anos antes na vanguarda europeia - Joyce e Virginia Woolf seus dois mais conspícuos praticantes -, esse contínuo remexer nas profundidades do eu não tinha sido posto em seres tão rústicos como os personagens de Fabiano. Para alguns críticos (LINS, 1993), a técnica é inverossímil: os seres "primitivos", se supõe, não pensam. Para Graciliano, em troca, até o próprio Fabiano pode se dar conta 
de seu erro depois de declarar: as crianças não pensam (RAMOS, 2001, p. 69). É verdade que a incorporação de um capítulo onde uma cadela esquadrinha suas sensações com tanta parcimônia parece igualar homens e animais (e, de novo, aparece Virgina Woolf e seu Flush). Mas, até onde se inclina o fiel dessa balança? "Fabiano, és um animal", insulta-se o protagonista de Vidas secas, e ao repetir o adjetivo para Baleia, esclarece: para ele era um elogio (RAMOS, 2001).

Junto a esse narrador em terceira pessoa esvaziado de voz autoral, surge uma das características mais chamativas deste romance, sua assim chamada "desarticulação". "Romance desmontável", disse Rubem Braga sobre esse romance do qual inclusive alguns capítulos foram publicados separadamente como contos, numa ordem que não segue a disposição que esses capítulos encontrariam no romance. O narrador que se distancia de seus personagens e que não emite nenhum tipo de explicação sobre eles ou sobre o próprio romance pode, contudo, não ser interpretado como forma negativa, como uma falta, e sim como uma forma da negação. Assinala, mais que uma desarticulação, outra forma de articulação baseada no rechaço de um tipo de linguagem explicativa que se relaciona intimamente com a explosão da voz autoral.

O terceiro: a língua. Um dos problemas recorrentes ao longo do romance, para diferentes personagens. O filho maior sente-se atraído pela palavra inferno, e sua curiosidade é motivo de surras e pancadas. A atração por um significante deriva em castigo, frustração, opressão e injustiça. A insistência nesta visão da linguagem ocupa praticamente cada capítulo: Fabiano não sabe falar e por isso mandam-no preso; Seu Tomás conhece palavras bonitas que não servem para salvá-lo da seca; o patrão utiliza as palavras para enganar Fabiano e roubá-lo. Junto à constante explicitação do trabalho com a língua, a construção dessa visão da linguagem conspira contra a obsessão fotográfica e documentalista. A linguagem, parece dizer Vidas secas, é mais performativa que representativa.

\section{Os limites do realismo}

Desarticulação, fragmentação e distanciamento do narrador foram vistos como formas realistas de sugerir "um mundo que não se compreende e se capta apenas por manifestações isoladas" (CANDIDO, 1978). Haveria nessa desarticulação "uma perfeita adequação da técnica literária à realidade expressada" (Idem, p. 114). Há nessa suposta adequação uma visão sobre a realidade expressada como realidade também fragmentária e inexplicável. Mas 
existe outra possibilidade que não se furta ao conflito entre uma utilização de técnicas que a vanguarda nos ensinou a não associar com a representação e uma representação da realidade regional. É possível pensar que a ponte entre realidade e representação é o que foi dinamitado: é impossível, sem ela, passar para o outro lado. Haver abandonado os pilares do realismo teria implicado postular para a literatura uma função diferente: um abandono da função mimética da literatura, uma insistência na necessidade de mudar os materiais da escrita. Explodir, em troca, esses pilares por dentro leva a outras conseqüências. Com dispositivos de representação da realidade utilizados como significantes vazios (LACLAU, 1996, p. 69-119), o que o romance de Graciliano Ramos demonstra é, não talvez a ausência de sentido, mas sim a recusa de constituir uma voz autoral à qual caberia o papel de articular esse sentido. Não haveria ali uma preocupação realista - representar mediante a desarticulação e a fragmentação a pretendida simplicidade de um pensamento rústico -, mas um deslocamento da política em direção a outro espaço. Assinalaria, em troca, uma concepção da linguagem como aquilo que, ainda que insista em representar a realidade, não pode contudo construí-la com um sentido acabado e completo. Com esse gesto o romance sugere uma crítica ao discurso que, ao denunciar, se torna cúmplice na tentativa de dar um sentido único e iluminado à experiência do outro. Como disse Haroldo de Campos, "o texto pobre denuncia a retórica da falação, da mais-valia bem falante" (CAMPOS, 1992, p. 228).

Não encontramos em Graciliano uma narrativa em que o que constitui a possibilidade de um sistema realista é também sua condição de impossibilidade. Seria então impossível pensar em Vidas secas como os limites do realismo? Não se não pensamos no limite somente como aquilo que funda uma exclusão, e sim no limite interno que se compromete com operações às que simultaneamente despoja de suas prebendas. Faltarão alguns anos e uma série de condições históricas e culturais diferentes para que Clarice Lispector, outra nordestina ainda que tenha nascido na Ucrânia - do outro lado do limite, rumine os pensamentos de Graciliano sobre a condição do intelectual e a representação do outro em $A$ hora da estrela.

Talvez esse pensamento dos limites tenha a ver em parte com o que lucidamente Candido viu como passagem de uma consciência de país novo - à qual caberia um regionalismo pitoresco e otimista - à consciência de país subdesenvolvido - à qual corresponderia um regionalismo problemático que desmistifica a realidade americana. De fato, se o otimismo da vanguarda implicava uma certa crença em que a renovação das formas traria uma 
renovação mais geral, esse regionalismo no limite pareceria, em troca, asseverar a modernização sem acreditar em seu destino irrefutável, esboçando as primeiras notas para uma reescrita do clássico ensaio de Benjamin, "O autor como produtor".

Segundo Flora Süssekind, a estética naturalista deve ser pensada no Brasil como uma faca de dois gumes: um cortante e outro cego. O gume cego condensaria o impulso conservador que busca a identidade e a nacionalidade sem fraturas, onde, concebida como câmara escura, a ideologia naturalista oculta os cortes e divisões. Mas haveria outro lado, o afiado, que é capaz de cortar e fraturar os modelos dominantes. Graciliano Ramos é esse gume nos anos 30, definindo-se como diferença em relação aos modelos aceitos, repetindo uma estética naturalista mas não seu caráter ideológico (Süssekind).

E é precisamente esse jogo com os limites do realismo o que faz Vidas secas instaurar um corte. A narrativa de Graciliano, e especialmente Vidas secas, encontra nessa afasia da linguagem a limpidez de uma faca, como o viu João Cabral de Melo Neto (1997) no poema "Graciliano Ramos":

Falo somente o que falo com as mesmas vinte palavras girando ao redor do sol que as limpa do que não é faca:

de toda uma crosta viscosa, resto de janta abaianada que fica na lâmina e cega seu gosto da cicatriz clara.

E se ficaram dúvidas a respeito da renovação que esta narrativa apresenta, resta-nos a imagem de Fabiano e sua família vagando feito peregrinos no deserto. Metáfora, segundo Zygmunt Bauman (1998), da modernidade.

\section{Bibliografia:}

ANDRADE, Oswald de. Estética e política. São Paulo: Globo, 1991.

BAUMAN, Zygmunt. Life in fragments. Essays in postmodern morality. Oxford and Cambridge: Blackwell, 1998.

BOSI, Alfredo. História concisa da literatura brasileira. São Paulo: Cultrix, 1972. 
BURTON, Julianne. Cine y cambio social en América Latina. Imágenes de un continente. México: Diana, 1991.

CAMPOS, Haroldo de. "Arte pobre, tempo de pobreza, poesia menos". Metalinguagem e outras metas. São Paulo: Perspectiva, 1992.

CANDIDO, Antonio. Ficção e confissão. Ensaios sobre Graciliano Ramos. São Paulo: Editora 34, 1992.

. "Literatura e subdesenvolvimento"; "A revolução de 30 e a cultura". A educação pela noite e outros ensaios. São Paulo: Ática, 1989.

. Tese e antítese. São Paulo: Companhia Editora Nacional, 1978.

CARVALHO, José Murilo de et al. Sobre o pré-modernismo. Rio de Janeiro: Fundação Casa de Rui Barbosa, 1988.

FOOT HARDMAN, Francisco. Nem Pátria, nem Patrão! Vida operária e cultura anarquista no Brasil. São Paulo: Brasiliense, 1983.

FREYRE, Gilberto. Manifesto regionalista. Recife: Instituto Joaquim Nabuco de Pesquisas Sociais\MEC, 1967.

LACLAU, Ernesto. "?Por qué los significantes vacíos son importantes para la política?". Emancipación y diferencia. Buenos Aires: Ariel, 1996.

LAFETÁ, João Luiz. 1930: a crítica e o modernismo. São Paulo: Duas Cidades, 2000.

LINS, Álvaro. Posfácio em Graciliano Ramos. Vidas secas. Rio de Janeiro: Record, 1993.

MELO NETO, João Cabral de. "Graciliano Ramos". Serial e antes. São Paulo: Nova Fronteira, 1997.

MORAES LEITE, Ligia Chiappini. "Velha praga? Regionalismo literário brasileiro". In: PIZARRO, Ana María (org.). América Latina: palavra, literatura e cultura. Vol. 2, Emancipação do discurso. São Paulo: Memorial; Campinas: Unicamp, 1994.

PAES, José Paulo. "O art nouveau na literatura brasileira". Gregos e baianos. São Paulo: Brasiliense, 1985.

PRADO, Paulo. "Poesia Pau-Brasil". In: ANDRADE, Oswald de. Obras completas, vol. VIII, Poesias reunidas. Rio de Janeiro: Civilização Brasileira, 1974.

RAMA, Ángel. Transculturación narrativa en América Latina. México: Siglo XXI, 1985.

RAMOS, Graciliano. Memórias do cárcere. São Paulo: Record, 1992.

- Vidas secas. Trad. Florencia Garramuño. Buenos Aires: Corregidor, 2001. 
RAMOS, Clara. "Elementos de biografia". In: GARBUGLIO, José Carlos et al. Graciliano Ramos. São Paulo: Ática, 1987.

RESENDE, Beatriz. Lima Barreto e o Rio de Janeiro em fragmentos. Rio de Janeiro: Editora da UFRJ, 1993.

RODRÍGUEZ MONEGAL, Emir. "Graciliano Ramos y el regionalismo nordestino". Narradores de esta América. Ensayos. Montevideo: Alfa, 1963.

SÜSSEKIND, Flora. Tal Brasil, qual romance? Uma ideologia estética e sua história: o naturalismo. Rio de Janeiro: Achiamé, 1984.

ZILIO, Carlos. A querela do Brasil. A questão da identidade da arte brasileira. Rio de Janeiro: Relume Dumará, 1982. 